\title{
Layering, Kludgeocracy and Disability Rights: The Limited Influence of the Social Model in American Disability Policy
}

\author{
Thomas F. Burke* and Jeb Barnes** \\ *Wellesley College \\ E-mail: tburke@wellesley.edu \\ ** University of Southern California \\ E-mail: barnesj@usc.edu
}

The United States has been a leader in the creation of disability rights law, providing a policy template for other nations. Yet the social model, the animating philosophy behind the disability rights movement, has had little effect on the wide range of welfare programs that serve people with disabilities. These programs, whose creation preceded the modern disability rights movement, reflect a medical model of disability that is at odds with the social model. Analysing the Americans with Disabilities Act (which embodies the social model) and Social Security Disability Insurance (the largest welfare program for people with disabilities), we explore how and why this layering of contradictory disability rights and welfare programs developed and how it has been maintained. We argue that the tension between these policies engendered a series of patches, or 'kludges', that allow the policies to coexist without meaningful synthesis. We contend that the United States is particularly prone to this layering of 'tense policies', but that it is likely characteristic of disability policy in many nations. Finally we argue that accurate benchmarking of disability rights regimes across nations requires analysts to dig through all the layers of disability policy.

Keywords: Social model, rights, Americans with Disabilities Act (ADA), Social Security Disability (SSDI) Insurance, layering.

The United States is the birthplace of the disability rights movement and of disability rights laws, most famously the Americans with Disabilities Act (ADA). These laws have been prototypes for disability rights policies adopted around the world, including the UN Convention on the Rights of People with Disabilities. There is almost certainly more disability rights litigation in the United States than anywhere else in the world, from mundane lawsuits governing wheelchair accessibility of fast food restaurants to landmark Supreme Court cases on the institutionalisation of disabled people and discrimination against people with HIV.

Yet once we get beyond the ADA and other disability rights laws, we see a striking pattern: to a great extent, disability policies that pre-existed the American disability rights movement operate just as they did before, even though they embody radically different 'policy paradigms' (Hall, 1993; Béland, 2007; Kay, 2007) or conceptions of disability and how to respond to it. The social model of disability, the animating set of ideas for the disability rights movement, seems to have little impact on how these policies function. 
Why has the disability rights movement had so little impact on the larger body of American disability policies? Sam Bagenstos, a leading American disability rights lawyer and scholar, points to the political diversity of the movement, suggesting that while it could converge to support disability rights, it has been much more divided about how to reform other aspects of disability policy, including disability welfare programs (Bagenstos, 2009). Bagenstos is surely right about the political complexity of the disability movement, but this complexity provides political opportunities as well as constraints on reform (Burke, 2002; Barnes and Burke, 2015). Indeed, the bipartisan coalition that passed the ADA agreed on the need to reform the welfare state to promote greater independence for people with disabilities. This coalition seemed a promising foundation for diffusing the social model. Yet reforming welfare programs has stalled, even as disability rights have proliferated.

We argue that this pattern is far from unique to American disability policy. It reflects the more general phenomenon of 'layering' (Schickler, 2001; Hacker, 2004; Streeck and Thelen, 2005). Layering occurs when reformers overcome entrenched interests to create new policies yet lack the power to replace existing policies. Newer policies do not displace older ones but are simply piled on top. Over time, layers of policy accumulate. Thus to understand, say, environmental or health policy, one must become a kind of geologist, digging through layers of policies that originate in different periods in political history and reflect different operating logics, support coalitions, partisan foundations and understandings of policy issues. Layering is particularly striking when the layers are out of synch with one another at the conceptual and programmatic levels. Adrian Kay (2007) has called this 'tense layering', and American disability policy provides a vivid example, as contradictory disability policies operate side-by-side, reflecting distinct partisan bases, conceptions of disability and assumptions about the role of social benefits in promoting independence.

Social scientists have mostly explored the causes of layering in public policy; less attention has been paid to its consequences. Kay's narrative of tense layering in Australian health policy is an exception. Kay describes how conflicting layers of Australian health policies were eventually accommodated and synthesised through the emergence of a new paradigm (Kay, 2007). Tense layering in American disability policy has not resulted in such a synthesis. The contradictions between layers of disability policy have been addressed primarily by 'kludges', temporary patches that have failed to resolve the contradictions or yield a new paradigm in disability policy.

In this article we draw on earlier work to explore the contradictions in American disability policy, focusing on conflicts between the Social Security Disability Insurance (SSDI) program, among the largest social welfare programs in the United States, and the ADA (Barnes and Burke, 2015). We then discuss how these policies evolved to produce the current pastiche. Along the way, we distinguish two concepts used to describe policy development, layering and 'kludgeocracy', which are related but distinct types of ad hoc policy development, and connect them to patterns of development that encompasses other policy change mechanisms, including 'conversion' and 'drift'. We then examine how the contradictions in American disability policy have been handled through a brief analysis of some episodes in which the ADA and SSDI have come into conflict. Finally, we consider how layering might affect international comparisons and benchmarking of disability rights regimes. 


\section{The contradictions of U.S. disability policy}

A dig through the layers of American disability could go quite deep, back to the early veteran's programs in the eighteenth and nineteenth Centuries that arguably formed the beginning of the American welfare state (Skocpol, 1995). We could consider, for example, the creation of 'sheltered workshops', in which people with disabilities work at subminimum wages (Stefan, 2010; Armsby, 2014), various tax policies that exclude many benefits provided to people with disabilities from taxation (and provide a special deduction for the blind) (Seto and Buhai, 2006), or the many rehabilitation programs that government has sponsored. The history of the institutionalisation of disabled people, and all the policies around that, amounts to several other layers.

In this article, we focus on the ADA and one particular disability policy, SSDI, created in 1956, well before the modern disability movement. We focus on SSDI because it is so consequential - in 2015, more than ten million Americans received SSDI benefits, including roughly 5 per cent of all working-age adults (SSA, 2015, Chart 1, 11; Table 8, 29) - but also because its assumptions about disability are so starkly at odds with those of the disability rights movement, and of more recent layers in disability policy, including the ADA. That said, SSDI is just one of several programs that provide benefits to people with disabilities in the United States, including state worker compensation programs, veterans programs and Supplemental Security Income (SSI), a sibling of SSDI that provides support for people with disabilities who have not worked long enough to qualify for SSDI.

These welfare programs arguably are at the core of popular understandings of disability. Indeed, as Stone argues, the concept of disability traces its origins to the beginnings of wage labor and the welfare state. 'Disability' was a category created to signify inability to work and thus was exempt from the normal understanding that male adults are breadwinners (Stone, 1984). The design of SSDI fits neatly into this tradition. To be 'disabled' for purposes of SSDI, applicants must prove that an impairment makes them unable to engage in 'substantial gainful activity' for at least a year, meaning that they are incapable of paid work during that period. To receive benefits, applicants have to wait until at least five months of unemployment have passed. SSDI applicants present medical and job information to state agencies that make initial eligibility determinations as a part of a complicated federal-state program structure. The strict eligibility criteria in the program reflect both understandings of disability when SSDI was enacted, well before the rise of the disability rights movement, and a deep concern about malingering.

SSDI was mainly a liberal Democratic program, and its champions in the 1950s had to convince more conservative members in their own ranks, as well as Republican President Eisenhower, that it would be limited in scope, compensating only those unable to work. The initial design of the program reflected those concerns, often at the expense of covering those suffering from legitimate but hard to prove ailments. Summer Schlicter, a Harvard economics professor and associate chairman of the Advisory Council on Social Security, an important blue ribbon commission established by the Senate, explained that SSDI reflected a cautious approach. He testified before Congress that the definition of disability intentionally limited eligibility to conditions 'medically demonstrable by objective tests. This rules out a lame back, lumbago, rheumatism, and so forth, if the symptoms are only subjective; it rules out some real disabilities, I am sorry to say, but it seemed necessary' (U.S. House of Representatives 1949: 1556). Nelson Cruikshank, director of social security issues for the American Federation of Labor (AFL), put it differently, explaining that 
program advocates 'compromised and compromised' to appease conservatives and their business allies (Derthick, 1979: 298). Whether one characterises the initial framing of SSDI as policy prudence or political compromise, the result was a program reflecting an explicitly medical definition of disability centered on the capacity to work.

SSDI has evolved from since its inception as a narrow program for workers with 'objective' disabilities (Autor and Duggan, 2006). From the 1950s to the 1970s, the program grew quickly and became firmly entrenched in the Social Security network dominated by powerful Democrats and policy professionals within the Social Security Administration (Derthick, 1979). A period of retrenchment in the 1970s culminated in the disability review fiasco of the 1980s, in which the Reagan Administration was pilloried for summarily cutting off SSDI recipients it deemed able to work. The backlash was intense, resulting not only in the curtailment of the disability review process, but, eventually, in a liberalisation of the criteria for eligibility. In assessing the inability to engage in 'substantial gainful activity,' the program officially began to consider not only an individual's impairments but also his or her job skills in relation to the economy. The result was a 'functional' definition of disability that stressed limits on workplace productivity. This broader assessment of disability resulted in another period of SSDI expansion that has largely continued today, buoyed by demographic factors such as the aging of the population and the move of women into the workforce (Erkulwater, 2006).

Despite these shifts, SSDI's fundamental design as a social insurance program in which disability is defined as an inability to work has never been seriously reconsidered. And though the program has expanded, the path to SSDI benefits remains arduous for most applicants. Between 2005 and 2014, an average of only 23 per cent of applications were initially approved. Many denied applicants then appeal, first to the program, then to a judge within the SSA, then, in a small number of cases, to the federal courts. According to the latest government program statistics, from 2005 to 2014, an average of only 35 per cent of all claims were ultimately approved (SSA, 2015: Chart 11, 147). In sum, SSDI remains firmly planted in what disability scholars call the medical model of disability, which defines disability in relation to individual impairment.

The medical model underlying SSDI sharply contrasts with the ideas underlying the disability rights movement. Around the world, the modern disability movement has been animated by the social model of disability, in which disability is understood as arising out of prejudice and discrimination rather than impairment; social barriers rather than physical maladies. The social model is the intellectual backbone of the disability movement, though of course some in the movement have criticised aspects of it (Shakespeare, 2013). As Dorfman has suggested, most disability scholars today embrace a more dialectical understanding of disability, seeing it as a complex interaction between individual impairment and social environment (Dorfman, 2017). This more nuanced understanding, however, remains fundamentally at odds with the medical model.

The American disability movement was profoundly influenced by the civil rights movement, emulating its tactics, rhetoric and approach to public policy. It embraced what has been called the 'minority model', the idea that people with disabilities are an oppressed group not unlike other minorities (Funk, 1987; Bowe, 1978; Hahn, 1996; Charlton, 1998). Closely aligned with this was the disability movement's embrace of what we have called the 'civil rights template' (Burke and Barnes, forthcoming), which addresses social injustices through lawsuits aimed at punishing individual acts of discrimination. For the American disability movement, at least, the social model, the minority model 
and the civil rights template seemed closely bound together. If disability stems from social arrangements, the thinking went, then that is a form of discrimination against an oppressed minority. It seemed almost automatic that providing the right to sue for discrimination was the appropriate remedy. This, after all, was the prototype that racial minorities, women and others had followed in a variety of policy areas.

These ideas were embodied in a series of statutes beginning with Section 504 of the 1973 Rehabilitation Act, a provision requiring nondiscrimination from federally funded entities that was modeled after parts of the 1964 Civil Rights Act (Burgdorf, 2015). The most famous disability rights statute is the ADA, enacted in 1990, which proscribes discrimination and mandates accessibility for people with disabilities in a wide range of activities, from employment and public transit to telecommunications and public facilities and programs. The ADA is enforced both by federal agencies and through lawsuits brought by individuals.

The politics of the ADA differ strikingly from that of SSDI. SSDI was a liberal program conceived as a supplement to Social Security, a crown jewel of the New Deal. As noted earlier, liberals convinced conservative Democrats and moderate Republicans to support SSDI by designing a narrow program administered by the states with a number of checks on federal involvement. The ADA was, by contrast, an ambitious law supported across the political spectrum, from left-wing disability activists to Reaganite anti-government conservatives. What brought them together, if summarised in one word, was 'independence'. This was the theme of a 1986 report by the National Council on the Handicapped ( $\mathrm{NCH}$ ) entitled 'Towards Independence' ( $\mathrm{NCH}, 1986)$, that contained the blueprint for the ADA. The report begins with an epigraph from President Theodore Roosevelt: 'Our country calls not for the life of ease, but for the life of strenuous endeavor' $(\mathrm{NCH}, 1986: 1)$. The $\mathrm{NCH}$ was dominated by Reagan appointees, and their report framed disability rights as a kind of welfare reform policy that would take people with disabilities off government benefits and into the labor force. This was a vision of independence refracted through the prism of anti-government conservatism, and shorn of the minority model with its analogy to the civil rights movement. In line with this vision, the $\mathrm{NCH}$ report urged Congress to reform SSDI so that recipients could work and retain at least some of their cash and health benefits. The report also recommended that all recipients be assessed for their employment potential, so that rehabilitation and placement services could be integrated into the payment system $(\mathrm{NCH}, 1986: 27-28)$.

Disability activists to the left of the $\mathrm{NCH}$ also valued independence, but their understanding of the principle differed in important ways. For them, independence meant liberation from the paternalism and pity embodied not just in government programs but more broadly in all the institutions and helping professions that tended to people with disabilities (Shapiro, 1994; Burke, 2002; Bagenstos, 2009: 22-33). This ethos was rooted in the independent living movement, which some would identify as the most important precursor to the disability rights movement. The independent living movement focused on liberating people with disabilities from their helpers, and giving them autonomy and choice in their lives (Dejong, 1979). The attitude towards the welfare system within the independent living framework is nuanced. To the extent welfare systems expect people with disabilities to meekly surrender autonomy to others, it is part of the problem. However, if the welfare system enables people with disabilities to control their own lives and treats them with dignity, there is no necessary problem with receiving government benefits (Bagenstos, 2009: 22-33). 
Thus the bipartisan coalition that enacted the ADA reflected a broad consensus on the promise of rights to empower people with disabilities, but a much more tenuous one on the role of welfare benefits in promoting independence. The policy outcomes reflected this asymmetry. With surprising speed, the $\mathrm{NCH}$ recommendation for a disability rights law was turned into a draft bill that was introduced into Congress (1988), overwhelmingly passed in revised form by the House and Senate (1989), and proudly signed into law by President George H.W. Bush (1990). Meanwhile proposals for SSDI reform went nowhere, despite criticisms of the program from both left and right.

The limits of the ADA support coalition as a welfare reform coalition were clearly revealed in the most ambitious post-ADA attempt to reform SSDI, the enactment of 'The Ticket to Work and Work Incentives Improvement Act of 1999'. Ticket to Work traces its origins to a think tank, the National Academy of Social Insurance (Mashaw and Reno, 1996), which proposed 'a radical new approach' to enable a return to work. First, the group urged Congress to let beneficiaries keep their Medicare health insurance for several years after returning to work. This sought to remove a crucial disincentive for employment, since many jobs in the United States come without health insurance, a particularly difficult problem for people with disabilities. Second, instead of relying on much-criticised state rehabilitation agencies to get SSDI beneficiaries into employment, the beneficiaries would receive a 'return to work ticket' that they could use for private or public rehabilitation services of their choice. If the beneficiary found a job, the provider could pocket a portion of the savings that this return to work generated. In theory, this voucher and rebate system gave beneficiaries more control while creating strong incentives for rehabilitation providers to get the beneficiary into a job.

Politically, this approach seemed to offer something for everyone. For those on the left, Ticket to Work extended Medicare services to give people with disabilities greater opportunities in the labor market. For those on the right, it included vouchers and the partial privatisation of rehabilitation services. But Ticket to Work was enacted only in diminished form, and after a tough fight. The fundamental problem was that the more ambitious proposals backed by Democrats ran into the fiscal conservatism of Republicans, who wanted assurance that any change in SSDI would not add to budget deficits. The original proposal by Democratic Senator Ted Kennedy would have cost more than $\$ 5$ billion; the law as signed was just 10 per cent of that, $\$ 500$ million, and included more ambitious ideas only as small-scale demonstration projects. As enacted, Ticket to Work extended Medicare benefits for 8.5 years after a beneficiary returned to work, but it did not include funding for devices or personal assistants that could be used to support employment. Perhaps the biggest limitation of Ticket to Work, though, is that it targeted those already receiving disability benefits. Scholars have long argued that medical care, personal assistance and other supports need to be provided to people with disabilities before they end up on SSDI (Barnes and Burke, 2015: 87). Ticket to Work was a humble proposal that produced modest results. Proponents had hoped to double the .5 per cent rate (five out of 1,000) at which SSDI beneficiaries return to work, but research suggested the law had little or no effect on employment (Stapleton et al., 2008; Liu and Stapleton, 2010; see also Barnes and Burke, 2015: 88 n.50).

Ticket to Work is a long way from a reconstruction of welfare programs along the lines of the social model of disability. Such a reconstruction might start by eliminating inability to work as a standard for compensation, and replacing it with a more graduated approach in which partial disability benefits could be combined with different types 
of work, including part-time and temporary jobs, and, where needed, supports such as devices and personal assistants that enable that work. According to one group of scholars, 'a growing portion of people with disabilities can work at some level but still need some type of assistance so that they can attain or maintain a reasonable standard of living' (Stapleton et al., 2006). But broad reform of SSDI would likely require a much greater investment of resources, or some kind of tradeoff in which benefits are reduced in order to fund a more activation-oriented program. Either of these alternatives would likely disrupt the left-right coalition that would be required to enact sweeping reform, going far beyond anything even Senator Kennedy, a leading liberal, had proposed.

The big fight over Ticket to Work, and its limited results, suggests that little opportunity exists for the more extensive reforms envisioned by disability advocates, just as there has proven to be limited support for the major retrenchments in disability welfare programs sometimes advocated by conservatives. Reform of the disability welfare programs has grown even more challenging as the political parties have further polarised on social policy. For these reasons, the main features of SSDI remain intact, largely untouched by the disability rights movement, the profusion of disability rights statutes, the social model of disability, or attacks on the welfare state.

\section{Tense layering and kludgeocracy in American disability policy}

American disability policy seems contradictory, even incoherent. That said, the U.S. pattern might not be unusual. As Heyer's comparative study of the U.S., Japan and Germany demonstrates, there is an international struggle to find some way to make sense of the contradictions between newly-adopted disability rights laws and older disability policies based on the medical model. Heyer describes, for example, the Japanese attempt to harmonise disability anti-discrimination law with a quota system - employers are required to hire a certain number of disabled workers - that has historically been the main approach to boosting employment of people with disabilities. More dramatically, Heyer describes the legal and political collision in Germany between the mandate for inclusive education of people with disabilities in the UN Convention on the Rights of Disabled Persons and the German system of highly segregated, specialised educational tracks (Heyer, 2015).

Disability activists in Japan and Germany, like those seeking to reform existing policies everywhere, are generally at a disadvantage. Pre-existing policies create constituencies and settled routines, and reform proposals usually anger those support coalitions. Those who benefit from the status quo usually work hard to protect it. So wholesale revision of existing policy is unusual. Instead, policy typically evolves in more complicated ways, and scholars have developed a rich vocabulary of concepts to describe these different forms of policy change. We consider four of these policy change concepts-- layering, kludgeocracy, conversion and drift - particularly relevant to the story of U.S. disability policy (see, e.g. Weir, 1992; Schickler, 2001; Streeck and Thelen, 2005; Hacker, 2004; Teles, 2013).

These concepts of policy change can be analogised to the ways in which one might go about refashioning a house. In 'revision', reformers replace existing policies, so that the house is torn down and rebuilt from scratch, creating an entirely new structure. In 'layering', reformers cannot entirely overcome entrenched interests and replace existing policies, so they add a new storey to the house, often in a style that is somewhat discordant 
with the original design. A 'kludge' (the term is taken from computer science) is a smallerscale addition: a patch that, rather inelegantly, is used to fix some problem with a law; as when a hole in the roof of a house is tarred over, or the leaks in a house's plumbing are patched rather than the piping replaced. A profusion of such patches, small ad hoc fixes rather than systematic reforms, creates a 'kludgeocracy' (Teles, 2013). In 'conversion', reformers re-purpose old policies to new ends: the interior of the house is remodeled, so that its exterior looks unchanged, but the rooms have been significantly reconfigured. In 'drift', changing circumstances have the effect of shifting policy, just as inflation changes the value of a paycheck. The house is left untouched but its value or functionality erodes, as when the family who lives in it grows so that the house no longer suits their needs.

These modes of policy change are sometimes treated in isolation, but they are often linked over time (Barnes, 2007, 2008, 2011; Béland, 2007; Kay, 2007). In disability policy, one could argue that the enactment of SSDI represented layering. Instead of fundamentally reforming the Social Security laws, a major disability insurance program was tacked on to the existing program, and then was quietly expanded through a series of piecemeal reforms. Over time, new conceptions of disability policy emerged, and the result was a kind of ideational drift, as SSDI grew out of step with these new conceptions. Drift, however, was not the end of the story. Instead, two policy paradigms of disability the traditional medical model versus the more open ended social model - engendered tensions over the definition of disability, and a complex politics that played out on multiple tracks (Erkulwater, 2006; Barnes and Burke, 2015).

One track involved SSDI. As Erkulwater (2006: 221-22) explains in her careful account, SSDI developed on two separate levels. On the 'macro level', there were some prominent examples of legislative battles over the program that produced some reforms, many of which eroded the original design and allowed the program to grow significantly. These moments of legislative activity, however, were the exception. Instead, most of the action was at the 'microlevel' and 'subterranean', as courts and agencies reinterpreted technical rules governing SSDI administration and program eligibility to make changes to the program from the inside out (Erkulwater, 2006: 222). The result was the partial conversion of SSDI, from the very narrow initial program to a broader one that reflected a more expansive definition of disability still tied to the medical model and the capacity to work.

Another track, of course, was the passage of the ADA. The ADA created a wholly new policy layer through legislation, one that reflected the social model. But the advocates of the ADA did not have the political power to revise all disability policy. Of course, part of the political argument for passing the ADA was that newly created rights would empower members of the disability community and, in the process, shrink the welfare rolls, but there was no accompanying reconstruction of the disability welfare system. Instead, the ADA created a new layer of policy designed to, among other things, expand access to governmental programs, public facilities and workplaces. The result was tense layering (Kay, 2007), as SSDI and the ADA reflect different ideas of disability (medical versus social model), different partisan coalitions (a liberal coalition among Democrats, administrators and beneficiaries as opposed to a bipartisan coalition among disability activists and small government conservatives) and different operational logics (a federalstate agency structure versus a regime that primarily uses private enforcement through litigation). The historian Edward Berkowitz (1987: 1) nicely summarises the result as a 
patchwork of programs and remedies 'born in many different eras' that 'reflect many styles of policymaking' as well as different conceptions of disability.

While this general pattern of disability policy seems far from unique, the United States may be particularly prone to tense layering because of its political structure and the growing polarisation of its political parties, which makes it difficult to replace existing policies with new ones or develop new policy paradigms that accommodate different layers. The American system of separated powers, often called 'presidentialism' by comparative scholars, disperses policy-making power among overlapping and diversely representative policy-making forums. Neustadt (1991: 34) once famously described this system as one of 'separated institutions sharing powers'. Under this system, legislation to change an existing policy must wind its way through a bifurcated Congress (including multiple committees and subcommittees), the Oval Office, executive agencies and the courts. This distinctively fragmented policymaking process has a number of implications for policy change. The most obvious is the creation of multiple veto points - opportunities to block, delay or water down new policy initiatives - which make it much easier for entrenched interests to resist change than for reformers to create new programs and policies (Immergut, 1990, 1992; Sundquist, 1992; Steinmo and Watts, 1995; Gerring and Thacker, 2008; Hacker and Pierson, 2010; Roof, 2014). This suggests that revision passing legislation that fully replaces existing policy - should be particularly rare in the United States (Oberlander, 2003a, 2003b). Yet the U.S. political system also offers multiple access points, opportunities for disgruntled groups to intervene in the system to initiate policy, so that groups that lose in the legislative process can turn to the courts or agencies and seek ad hoc policy adjustments and exceptions that can erode policy coherence (Berkowitz and DeWitt, 2013; see also Melnick, 1994; Nolette, 2015). The combination of multiple veto and access points seems to make the United States particularly prone to layering and kludgeocracy (Teles, 2013).

\section{The consequences of tense layering in disability policy}

To this point, we have considered the ways in which the different layers of disability policy are in tension, but we have not described the consequences of tense layering. How do those charged with implementing public policies operate in a world in which those policies contradict one another? To what extent and under what conditions do polities with contradictory policies address those contradictions? This is a complicated set of questions and we do not offer a general theory that attempts to answer them here. Like so many issues related to policy development, the outcomes of tense layering seem tied up with historical contingencies and context-specific factors. In Australian health care, tense layering between a universal public health system and a private health insurance system eventually gave way to a synthetic policy paradigm in which the public universal health and private insurance systems were eventually seen as integral, offering complementary and mutually reinforcing components of their health care system (Kay, 2007). In American disability policy there has been no policy synthesis. Instead, the different layers of disability policy continue to rub up against each other, forcing policymakers to 'muddle through' contradictions (Lindblom, 1959). In American disability policy, tense layering has resulted in a series of kludges that have allowed the layers to co-exist without meaningful integration. 
This process is vividly illustrated in the continuing controversy over the definition of 'disability' in the ADA. The ADA's formal definition of disability reflects its social model origins. To be considered disabled, and thus eligible to bring a discrimination lawsuit, one must be 'substantially limited in a major life activity' (42 U.S.C. 12102(2)(A)). The drafters of the ADA clearly thought this language swept much more broadly than the corresponding 'unable to engage in substantial gainful activity' definition in the SSDI program; in the preamble to the ADA they estimated that the statute applied to forty-three million Americans with disabilities, which is more than four times the current number of SSDI beneficiaries. Of course, the sweep of the statute depended on how the key terms 'substantially limited' and 'major life activity' were interpreted. The drafters of the ADA may have thought the terms were unproblematic: The language was lifted from the regulations implementing the first major disability rights statute Section 504, which had been argued over in the legal system for more than a decade and seemed battle-tested.

But sophisticated lawyers defending ADA lawsuits quickly took advantage of the ambiguities in these terms, and leveraged the prevalence of the medical model of disability in American public policy and culture. On one hand, defense lawyers argued that plaintiffs were in fact too disabled for employment, not really 'qualified individuals' because they could not perform the 'essential functions' of the job as required under the ADA. On the other hand, they argued that plaintiffs were not really people with disabilities under the statute, because they were not substantially limited in a major life activity (Burke, 2004: 127-30), contending either that the major life activity proffered by plaintiffs were not major enough, or their limitations were not substantial enough. Federal courts, concerned about the sweep of the ADA, branded plaintiffs with breast cancer, strokeinduced paralysis, a brain tumor, epilepsy, depression, cancer and carpel tunnel syndrome as non-disabled under the statute (Diller, 2000: 24-6). The two-sided defense put ADA plaintiffs in a double bind, either considered too disabled or not disabled enough to benefit, at least from the employment section of the law.

These issues provide a textbook example of how competing policy paradigms in a system of tense layering can undermine the functionality of a policy. If disability in the larger culture means 'inability to work', as embodied in the SSDI program, it is hard to make sense of the ADA, which is premised on the belief that most people with disabilities can work on an equal basis with the non-disabled, if prejudice is confronted and relatively low-cost accommodations are made. The judges who heard ADA lawsuits may have been bringing a medical model of disability to bear when they ruled in these cases. Certainly, the effect of these decisions was to focus on the extent of the plaintiffs' impairment and ability to work, consistent with the medical model, as opposed to considering whether employers were making reasonable accommodations, consistent with the social model.

Eventually, the profusion of anti-plaintiff rulings encouraged the initial proponents of the ADA to return to Congress, which produced the ADA Amendments Act (ADAAA) in 2008. The ADAAA sought to clarify the definition of disability, particularly what counts as a 'substantial limitation' and what sorts of things are 'major life activities'. The ADAAA instructs judges to construe the statute 'in favor of broad coverage of individuals' (42 U.S.C. 12102(4)(A)). Thus Congress was clearly attempting to widen the ADA's definition of disability, and in so doing further push it away from the more narrow definition in SSDI. Yet the ADAA leaves room for interpretation and it seems likely that litigation will continue over the scope of the statute. In the words of Charles Lindblom (1979), this is an issue over which Americans are 'still muddling, not yet through'. 
The ongoing fight over the definition of disability under the ADA reflects how the different policy paradigms arguably spill over, as concepts from one layer seem to cast a shadow over the interpretation of another. In other instances, the layers come into direct conflict, as when a person's application to receive benefits under SSDI is used as evidence against her eligibility to bring an ADA lawsuit. In these cases, the logic of the SSDI, in which impairment is deemed too severe to make one able to work (and thus deserving of benefits), runs up against the vision of the ADA, in which the barrier is prejudice and lack of accommodation, not merely impairment. In the first few years after the ADA was enacted, employers defended ADA discrimination lawsuits by claiming that by applying for SSDI benefits, an individual was declaring him or herself unable to engage in substantial gainful activity and thus clearly not someone who could perform the essential functions of a job, a requirement to bring an ADA claim. This argument was often successful, as many courts invoked the doctrine of judicial estoppel, meaning that the matter of whether an individual was qualified to be employed - whether they could perform essential functions of a job as per the ADA - had already been legally resolved when individuals had declared themselves unable to engage in substantial gainful activities as required under SSDI (Houghton, 1998).

The Supreme Court weighed in on this issue in 1999, in Cleveland v. Management Policy Systems (526 U.S. 795), a case involving a woman who had suffered a stroke that impaired her memory and concentration, and was subsequently fired from her job doing background checks on job applicants. The woman successfully applied for SSDI benefits, but then brought a lawsuit against her employer arguing that she could have been kept in her job with reasonable accommodations. The lower courts disagreed, ruling that she had failed to explain how she could be a qualified individual with a disability under the ADA when she had claimed total disability in her SSDI application.

Faced with a case that brought the contradictions between two disability policies into sharp focus, Justice Stephen Breyer, who wrote for a unanimous Court, tried to strike a balance, allowing the policies to coexist without fully resolving their underlying conflict. As a formal matter, he insisted that 'these two seemingly divergent statutory contentions' - that an applicant for SSDI deserves welfare benefits because of an inability to work, and that a plaintiff with a disability was discriminated against when she was fired - 'are often consistent, each with each other' (526 U.S. 797). Breyer noted that to be qualified for employment under the ADA, one must do the 'essential functions' of a job 'with reasonable accommodation' (803 [emphasis in original]). SSDI, by contrast, fails to consider whether an applicant could work if her impairment was in some way accommodated by an employer. Thus if an employer failed to provide reasonable accommodation, a fired employee might properly be eligible both for SSDI benefits and an ADA discrimination claim.

Breyer further noted that the Social Security Administration (SSA), which administers the disability benefits system, processes a huge volume of applications, 2.5 million in the year before his ruling, and so might in many cases grant an award in a case where an individual might still be capable of work. Indeed, Breyer pointed out that the SSA under some conditions allowed SSDI beneficiaries to work for several months without being cut off from benefits (803). Finally, Breyer noted that for someone who had applied for but not yet received benefits, courts should follow what he described as an ordinary rule of law, one that might befuddle non-lawyers: litigants can advance two legal theories that logically contradict one another if they are unsure which is more likely to succeed (805). 
In this respect, Breyer embraced the contradiction between the two programs, arguing that judges regularly encounter contradictory claims as plaintiffs provide alternative legal grounds for recovery.

While the Cleveland ruling opened up some space for dual SSDI/ADA claimants, it did not resolve the conflicts between the statutes - it was more of a 'kludge' than a synthesis. In explaining his decision, Breyer concluded that an ADA plaintiff 'cannot ignore the apparent contradiction' that arises from an earlier SSDI claim and so had the burden of adequately explaining it, leaving lower courts to decide what counted as a sufficient explanation. Moreover, Breyer noted that, while apparent legal contradictions inherent in dual SSDI/ADA claiming could be finessed, factual statements in SSDI applications by dual claimants could be grounds for dismissing an ADA lawsuit (807). This again left lower courts the task of deciding which types of factual contradictions were disqualifying and which could be overlooked, in the process engendering patchwork policy-making at the microlevel, as trial judges scattered across the country were asked to make policy on a case-by-case basis.

This is not a criticism of Breyer's earnest attempt to reconcile these layers of disability policy. He could do only so much. His emphasis on the provision of 'reasonable accommodation' in the ADA, and the absence in SSDI of any consideration of how accommodations might improve the job prospects of applicants, touched on a key difference between the welfare and rights layers of disability policy. Where SSDI largely locates disability in the individual, as in the medical model, the ADA is based on an assumption that disability is in part created by social structures, so that bending those structures through accommodations is the proper response. In fact, the SSA considered at one point including an assessment of how possible accommodations might affect the job prospects of applicants. The idea was, however, soon abandoned (Diller, 1998: 1049-50). As Breyer suggested, the SSA must process millions of disability claims each year, and it seems hard to imagine that the agency could engage in the highly contextualised inquiry necessary to judge the impact of (hypothetical) job accommodations on an applicant's ability to work.

From the social model perspective, the limitations of SSA's adjudicatory processes only underscore the costs of tense layering and the failure of the social model to diffuse more broadly. Instead of trying to finesse these tensions, advocates would ask whether SSA should become a different kind of agency, one more focused on maximising the quality of life of people with impairments through all kinds of interventions, including assessing needed accommodation and assistance that would allow them to work as productively as possible (Diller, 1998). Critics contend that the Cleveland ruling has left dual applicants in a treacherous position, as courts 'continue to find irreconcilable conflicts between ADA and SSDI claims, often through overly formalistic or technical analyses' that fails to consider why, for example, a person who has just lost a job after becoming impaired may seek both the source of livelihood through disability benefits and reinstatement in a job through the ADA (Lowe, 2009: 1248).

Thus the task of muddling through the tense layers of disability policy has fallen to federal judges, while the troubles caused by their patchy rulings have been borne primarily by dual applicants. The example, and the problem itself, may seem to some observers to be 'marginal', not only in the literal sense - these problems of layering are manifest by cases that appear at the margins of each policy (the ADA plaintiff who struggles to establish her legal standing; the SSDI claimant whose impairments seem too minor to 
establish eligibility) - but also in the evaluative sense, of being unimportant, a minor aspect of disability policy. We contend, however, that these cases are worthy of study, not just because they make the contradictions between layers particularly vivid, but because they exemplify how tense layering engenders the emergence of kludgeocracy that erodes policy coherence.

\section{The measurement of disability rights}

Is the United States a land of disability rights? To answer that question, we would typically focus on disability rights statutes: the ADA, the Individuals with Disabilities Education Act, Section 504, and many other state and federal laws that are at least partly framed as rights policies, and which seem to reflect in part the precepts of the social and minority models of disability. We might evaluate how well these laws have worked, looking at patterns of litigation, court decisions, agency actions, and statistical outcomes.

But such an assessment would miss a lot. SSDI and the other disability welfare programs are arguably the most important disability policies in the United States, directly affecting far more people and resources than the rights laws. And we have not even considered other layers of disability policy - labor laws that allow for subminimum wage employment of people with disabilities, rehabilitation programs, tax policies and many other aspects of public policy that still reflect the medical model's understanding of disability. By examining the other layers of disability policy, we place rights in a much broader landscape, and in so doing reveal some of the most formidable barriers to the diffusion of the social model.

The need to account for different layers of policy in assessing rights may be particularly acute in the U.S., where layering and kludgeocracy are staple features of all kinds of public policies, not just in the field of disability. It is certainly possible that nations with stronger traditions of state action and parliamentary systems of government may be more apt to create synthetic policy paradigms that promote both rights and welfare programs, resulting in 'synergistic layering' as opposed to 'tense layering'. We suspect, however, that tense layering will be characteristic of disability policy in many nations because of the fundamental contradiction between the social model that animates disability rights and the definition of disability as the inability to work that lies at the core of other welfare programs. Disability rights represents a new policy paradigm that challenges many aspects previous disability policies, and the political alignments that enacted disability rights may be quite different from the coalitions that have created and supported older disability policies. Scholars of disability rights must dig down to all the layers - and find the policy that emerges from the interstices and points of conflict between them.

\section{References}

Armsby, J. G. (2014) 'The war on sheltered workshops: will ADA Title II discrimination lawsuits terminate an employment option for adults with disabilities?', Georgia State University Law Review, 31, 443-70. Autor, D. and Duggan, M. (2006) 'The growth in the Social Security Disability rolls: a fiscal crisis unfolding', Journal of Economic Perspectives, 20, 3, 71-96.

Bagenstos, S. R. (2009) Law and the Contradictions of the Disability Rights Movement, New Haven, CT: Yale University Press. 
Barnes, J. (2007) 'Rethinking the landscape of tort reform: lessons from the asbestos case', Justice Systems Journal, 28, 2, 157-81.

Barnes, J. (2008) 'Courts and the puzzle of institutional stability and change: administrative drift and judicial innovation in the case of asbestos', Political Research Quarterly, 61, 636-48.

Barnes, J. (2011) Dust-Up: Asbestos Litigation and the Failure of Commensense Policy Reform, Washington, D.C.: Georgetown University Press.

Barnes, J. and Burke, T. F. (2015) How Policy Shapes Politics: Rights, Courts, Litigation and the Battle over Injury Compensation, New York: Oxford University Press.

Béland, D. (2007) 'Ideas and institutional change in Social Security: conversion, layering and policy drift', Social Science Quarterly, 88, 1, 2-38.

Berkowitz, E. (1987) Disabled Policy: America's Programs for the Handicapped, New York: Cambridge University Press.

Berkowitz, E. and DeWitt, L. (2013) The Other Welfare: Supplemental Security Income and U.S. Social Policy, Ithaca, NY: Cornell University Press.

Bowe, F. G. (1978) Handicapping America: Barriers to Disabled people, New York: Harper \& Row.

Burgdorf, R. (2015) 'A dozen things to know about the ADA on its $25^{\text {th }}$ anniversary', http://www.law.udc. edu/?ADAAnniversary [accessed 07.09.2017].

Burke, T. F. (2002) Lawyers, Lawsuits and Legal Rights: The Struggle over Litigation in American Society, Berkeley: University of California Press.

Burke, T.F. (2004) Judicial Implementation of Statutes: Three Stories About Courts and the Americans with Disabilities Act, in M. Miller \& J. Barnes (eds.), Making Policy, Making Law: An Interbranch Perspective, Washington D.C.: Georgetown University Press, 123-138.

Burke, T. F. and Barnes, J. (forthcoming) 'The civil rights template and the Americans with Disabilities Act: a socio-legal perspective on the promise and limits of individual rights," in L. Dodd (ed.), The Rights Revolution Revisited: Institutional Perspectives on the Role of Private Enforcement of Civil Rights in the U.S., New York: Cambridge University Press.

Charlton, J. I. (1998) Nothing About Us Without Us: Disability Oppression and Empowerment, Berkeley: University of California Press.

DeJong, G. (1979) 'Independent living: from social movement to analytic paradigm', Archives of Physical Medicine and Rehabilitation, 60, 10, 435-46.

Derthick, M. (1979) Policymaking for Social Security, Washington, D.C.: Brookings Institution.

Diller, M. (1998) 'Dissonant disability policies: the tensions between the Americans with Disabilities Act and federal disability benefit programs', Texas Law Review, 76, 1003-82.

Diller, M. (2000) 'Judicial backlash, the ADA, and the civil rights model', Berkeley Journal of Employment and Labor Law, 21, 1, 19-52.

Dorfman, D. (2017) 'Re-claiming disability: identity, procedural justice, and the disability determination process', Law and Social Inquiry, 42, 1, 195-231.

Erkulwater, J. (2006) Disability Rights and the American Social Safety Net, Ithaca, NY: Cornell University Press.

Funk, R. (1987) 'Disability rights: from caste to class in the context of civil rights', in A. Gartner (ed.), Images of the Disabled, Disabling Images, Westport CT: Praeger Publishers, 7-30.

Gerring, J. and Thacker, S. C. (2008) Good Government: A Centripetal Theory of Democratic Governance, New York: Cambridge University Press.

Hacker, J. (2004) 'Privatizing risk without privatizing the welfare state: The hidden politics of social retrenchment in the United States', American Political Science Review, 98, 2, 243-60.

Hacker, J. and Pierson, P. (2010) Winner-Take-All Politics: How Washington Made the Rich Richer and Turned its Back on the Middle Class, New York: Simon \& Schuster.

Hahn, H. (1996) 'Antidiscrimination laws and social research on disability: the minority group perspective', Behavioral Sciences and the Law, 14, 41-59.

Hall, P. A. (1993) 'Policy paradigms, social learning and the state', Comparative Politics, 25, 275-96. 
Heyer, K. (2015) Rights Enabled: The Disability Revolution, from the U.S., to Germany and Japan, to the United Nations, Ann Arbor, MI: University of Michigan Press.

Houghton, K. L. (1998) 'Having total disability and claiming it, too: the EEOC's position against the use of judicial estoppel in Americans With Disabilities Act cases may hurt more than it helps', Alabama Law Review 49, 645-672.

Immergut, E. M. (1990) 'Institutions, veto points, and policy results: a comparative analysis of health care', Journal of Public Policy, 10, 4, 391-416.

Immergut, E. M. (1992) Health Politics: Interests and Institutions in Western Europe, New York: Cambridge University Press.

Kay, A. (2007) 'Tense layering and synthetic policy paradigms: the politics of health insurance in Australia', Australian Journal of Political Science, 4, 579-91.

Lindblom, C. (1959) 'The science of "muddling through",' Public Administration Review, 19, 2, $79-88$.

Lindblom, C. (1979) 'Still muddling, not yet through', Public Administration Review, 39, 6, 517-29.

Liu, S. and Stapleton, D. (2010) 'How many SSDI beneficiaries leave the rolls for work? More than you might think', Disability Policy Research Brief, 10-01, 1-4.

Lowe, L. (2009) 'What employees say, or what employers do: have post-Cleveland decisions continued to obscure discrimination?', Vanderbilt Law Review, 62, 4, 1245-83.

Mashaw, J. L. and Reno, V. P. (1996) Balancing Security and Opportunity: The Challenge of Disability Income Policy; Final Report of the Disability Policy Panel, Washington, D.C.: National Academy of Social Insurance.

Melnick, R. S. (1994) Between The Lines: Interpreting Welfare Rights, Washington D.C.: The Brookings Institution.

National Council on the Handicapped (NCH) (1986) Toward Independence, Washington D.C.: U.S. Government Printing Office.

Nolette, P. (2015) Federalism on Trial: State Attorneys General and National Policymaking in Contemporary America, Lawrence: University of Kansas.

Neustadt, R. (1991) Presidential Power and the Modern Presidents: The Politics of Leadership from Roosevelt to Reagan, New York: Macmillan Press.

Oberlander, J. (2003a) The Political Life of Medicare, Chicago: University of Chicago Press.

Oberlander, J. (2003b) 'The politics of health reform: why do bad things happen to good plans', Health Affairs Web Exclusive, W3-391, 27 August.

Roof, T. (2014), 'Interest groups', in D. Beland, C. Howard and K. J. Morgan (eds.), The Oxford Handbook of Social Policy, New York: Oxford University Press, 187-204.

Schickler, E. (2001) Disjointed Pluralism: Institutional Innovation and Development of the U.S. Congress, Princeton, N.J.: Princeton University Press.

Seto, T. P. and Buhai, S. L. (2006) 'Tax and disability: ability to pay and the taxation of difference', University of Pennsylvania Law Review, 154, 1053-145.

Shakespeare, T. (2013) Disability Rights and Wrongs Revisited, London: Routledge.

Shapiro, J. P. (1994) No Pity: People with Disabilities Forging a New Civil Rights Movement, New York, N.Y: Times Books.

Skocpol, T. (1995) Protecting Soldiers and Mothers: The Political Origins of Social Policy in the United States, Cambridge, Mass.: Harvard University Press.

Social Security Administration (SSA) (2015) Annual Statistical Report on the Social Security Disability Insurance Program, 2015, https://www.ssa.gov/policy/docs/statcomps/di_asr [accessed 10.09.17].

Stapleton, D. C., O'Day, B. L., Livermore, G. A. and Imparato, A. J. (2006) 'Dismantling the poverty trap: disability policy for the twenty-first century', The Milbank Quarterly, 84, 4, 701-32.

Stapleton, D. C., Livermore, G., Thornton, C., O’Day, B., Weathers, R., Harrison, K., So, O., Martin, E., Wittenburg, D. and Wright, D. (2008) Ticket to Work at the Crossroads: A Solid Foundation with an Uncertain Future, Washington D.C.: Mathematica Policy Research.

Stefan, S. (2010) 'Beyond residential segregation: the application of Olmstead to segregated employment settings', Georgia State University Law Review, 26, 875-935. 
Steinmo, S. and Watts, J. (1995) 'It's the institutions, stupid! Why comprehensive national insurance always fails in America', Journal of Health Politics, Policy and Law, 20, 329-423.

Stone, D. (1984) The Disabled State, Philadelphia: Temple University Press.

Streeck, W. and Thelen, K. (2005) 'Introduction: institutional change in advanced political economies', in W. Streeck and K. Thelen (eds.), Beyond Continuity, New York: Oxford University Press, 1-35.

Sundquist, J. (1992) Constitutional Reform and Effective Government, Washington, D.C.: Brookings Institution.

Teles, S. (2013) 'Kludgeocracy in America', National Affairs Fall, 97-114.

U.S. House of Representatives (1949) Social Security Act Amendments of 1949, Part 2: Old-Age, Survivors and Disability Insurance, March 24-April 27.

Weir, M. (1992) 'Ideas and the politics of bounded innovation', in S. Steinmo, K. Thelen and F. Longstreth (eds.), Structuring Politics: Historical Institutionalism in Comparative Analysis, New York: Cambridge University Press, 188-217. 